\title{
OVERCOMING SEED DORMANCY OF Robinia pseudoacacia L. AND Ceratonia siliqua L. SPECIES USING DIFFERENT PRETREATMENTS IN MALTA FOREST NURSERY - DUHOK
}

\author{
Khaleda HaJi Abdullah ${ }^{1}$; Gailan B. Ahmed ${ }^{*}{ }^{2}$, Mohammed T. SElah-Alden; Hizer Nori \\ Hassan; Mohammed J. Mahmood; NARin Ali Hameed ${ }^{3}$ and SAMi MoHAmed Amin ${ }^{4}$ \\ ${ }^{1}$ Dept. of forestry, College of Agriculture, University of Duhok, Kurdistan Region-Iraq \\ ${ }^{2}$ Dept. of forestry, College of Agriculture, University of Duhok, Kurdistan Region-Iraq \\ ${ }^{3}$ Directorate of Malta forest Nursery, Ministry of Agriculture, Duhok, Kurdistan Region-Iraq \\ ${ }^{4}$ Dept.of Recreation and Ecotourism, College of Agriculture,University of Duhok,Kurdistan Region-Iraq
}

(Received: September 31, 2017; Accepted for publication: May 24, 2018)

\begin{abstract}
Seeds of the legume species are characterized by physical hard seed coat dormancy. Several pre-sowing treatments were tested of these species to enhancing seed germination. This study was carried out in the Malta Forest Nursery to increasing the germination percentage of (Robinia pseudoacacia) and (Ceratonia siliqua) seeds. The experiment was laid out in randomized complete design with four replications. Both species, seeds were soaked in hot water at $\left(80 \mathrm{C}^{\circ}\right)$ for 30,60 and $90 \mathrm{~min}$, and mechanical scarification; the second trait seeds treated with factorial experiment which were seeds of both two species soaked in sulfuric acid for 30,60 and $90 \mathrm{~min}$, and then immersed in tap water for 24,48 and $72 \mathrm{~h}$. The results showed that the seeds of Robinia pseudoacacia species treated with hot water for $60 \mathrm{~min}$ were increased germination percentage $(63.75 \%)$, and the same result obtained of Ceratonia siliqua seeds treated with hot water for 60 $\min (61 \%)$. In the factorial experiment, the seeds of Robinia pseudoacacia species were treated with Sulfuric acid scarification at $90 \mathrm{~min}$, then immersed with tap water for $24 \mathrm{~h}$ were the best result of germination percentage $(42.5 \%)$. In Ceratonia siliqu seeds were treated with sulfuric acid at $60 \mathrm{~min}$ and soaking with tap water for $24 \mathrm{~h}$ increased the seed germination percentage $(65 \%)$.
\end{abstract}

KEYWORD: legume species, dormancy, sulfuric acid, mechanical scarification.

\section{INTRODUCTION}

B Lack locust (Robinia pseudoacacia) and Carob (Ceratonia siliqua) both are woody legume species where enhanced physical seed dormancy and their persistent soil profile (Richardson and Kluge 2008). These trees have been grown in the most countries of the Mediterranean region and has accordingly become one of the most important woody plant invaders and naturalized in Asia and Australia as well as in the Western and Central part of North America (Batlle and Tous, 1997; Holle et al. 2006).

These species are mainly propagated vegetatively in nature with high adaptability and nitrogen-fixing character (Ortiz et al. 1995 and Rice et al. 2004). The legume seeds have been prolonged by antimicrobial proteins accumulated in the seed tissues making them resistant to most pathogens (Talas-Ogras et al. 2005).
These species are economically important trees and they can be used in many tree-planting purposes: charcoal, wood production, soil erosion control, land reclamation and ornamental trees (Batlle and Tous, 1997). Both species were used in Mediterranean countries and they recommended for afforestation of degraded coastal areas threatened by soil erosion and desertification and often used in ornamental plantings and to regenerate disturbed sites in the parks and Agroforestry in nutrient deficient (Batlle and Tous, 1997).

Fruits and seeds in both of $R$. pseudoacacia and $C$. siliqua are low reproductive yield; most ovules fail to develop within the mutliseeded fruits of both species (Susko, 2006).

Seed germination is influenced by the environmental factors including temperature, water, oxygen, light and the chemicals (Tlig et al. 2008). The water content of the seed is a critical 
factor to trigger cell elongation and initiate radical emergence (Baskin and Baskin, 2014). Rising of temperature from (40 up to $45^{\circ} \mathrm{C}$ ) may be decreased germination percentage of carob species, but the optimum temperature is within $\left(25-30^{\circ} \mathrm{C}\right)$ for germinability of carob seeds (Lamlom and Abdalrasol, 2016).

The two tree species (Black locust and carob) have different germination percentage in the nursery for planting purposes. They are useful for stands or forests on medium and poor quality sites. They are utilized for the production of fuel wood, fodder, poles and props, as well as soil erosion control and environmental improvement (Zeleznik and Skousen 1996).

The applications of pre-sowing methods, including acid and mechanical scarification are exogenous treatments have been used to breaking hard seed coat and improve seed germination (Bonner et al., 1994; Masaka and Yamada, 2009; Lamlom and Abdalrasol, 2016).

The last decades have been an increasing demand for woody legume species, plantations of these species in forestry expanded to using a much broader range of species, so that a wider set of sites is exploited or restored for economic and conservation purposes (Weber 2003).

Both tree species of Fabaceae family have hard and impermeable seed coats caused physically dormancy (Zoghi et al., 2011).

This study aimed to determine the best treatment for breaking dormancy and increasing seed germination of both legume species.

\section{MATERIALS AND METHODS}

The experiment was carried out in the field of Malta forest nursery- Duhok, General Directorate of Forestry and Rangeland (Duhok Province).

Fruits (Pods) containing mature seeds of Carob and Black locust were harvested after mature brown seeds in autumn (10 November, 2015). After the collection, seeds were extracted and cleaned manually and placed in paper bags, then stored dry under laboratory conditions at about $25^{\circ} \mathrm{C}$ until the start of the experiments 20-March 2016. Seeds of both species were dipped into the water and floating seeds were removed.

Two experiments were conducted; the first one was carried out of both two species; by using with the following pre-sowing treatments:

- Control (untreated seeds).
- Mechanical scarification was performed manually with sand-paper.

- Soaking in Hot water at $\left(80 \mathrm{C}^{\circ}\right)$ for $30 \mathrm{~min}$., 60 min and 90 min.

The second experiment was carried out factorial experiment with seeds of both two species soaking in Sulfuric acid (98\%) for 30 min., 60 min., 90 min. and then immersion in tap water for 24,48 and $72 \mathrm{~h}$ ( $3 * 3$ interaction).

In hot water, seeds were placed in a cloth bag and then dipped into hot water $\left(80 \mathrm{C}^{\circ}\right)$, after that immersion seed were allowed to cool water to laboratory temperature. After Sulfuric acid (98\%) scarification for each duration, seeds were washed several times with water to remove acid.

The seeds were kept in pots (container) containing soft soil after treatments. The two experiments of both species were designed according to randomize complete design (CRD) with four replications 25 seeds were used for each replicate.

Before analysis the percentages were transformed to arcsine values. All data were analyzed using ANOVA model (SAS software, 2001), and the Duncan test was used for the comparison of the means between the different treatments.

\section{RESULTS AND DISCUSSION}

\section{- The First Experiment:}

The results of the effect of treatments had significant differences at 0.01 levels (Table 1). Means of seed germination percentage of Robinia pseudoacacia from the Duncan test showed that in test one was various significant among them. The highest germination percent $(63.75 \%)$ was shown in hot water treatment for $60 \mathrm{~min}$, while the lowest value was untreated seeds (control) (20.63\%) (Table 2).This same result was reported with Bagas, et al. (2010) by using acid treatment to improve the germination percentage of black locust seeds; also results found by Saikou, et al.(2008) that treating Acacia Senegal with hot water for $10-40$ minutes gave the best results. Pipinis, et al. (2011), were using hot water and Sulfuric acid on breaking seed coat of Tamarind and Acacia seeds which were increased seed germination clearly.

On the other hand, Gebre and Keram (2004) are used hot water treatment for increasing seed 
germination of Cercis siliquastrum, and Nasiriand Eisvand (2001) with Albizia julibrissin species.

The seed of Gleditsia triacanthos L. for soaking in hot water at $90 \mathrm{C}^{\circ}$ for 20 minutes was the best method for breaking seed dormancy (Ahmed, 2015).

Soften hard seed coat of Robinia pseudoacacia L. and improving seed germination which treated with hot water (Mitra, et al. 2013), and the same effect on Gleditsia triacanthos (Basbag, et al. 2010 and Vasichkina, et al. 2014; Poşta and Camen, 2015).
The seeds of Ceratonia siliqua species in comparison means of Duncan test; the highest germination was soaking in (60 mints) of hot water $(61 \%)$, whereas the lowest value $(11 \%)$ germination percentage was observed with seeds were mechanically scarified (Table 2). Similarly, these results were observed with Perez-Garcia (2009) who used different pre-sowing to improving the seed germination of carob and found the highest germination in Carbo (Tsakaldimi \& Ganatsas (2001), Nasiri and Eisavand (2001) on Albizia julibrissin and Ceratonia

Table (1): Variance of analysis of the germination percentage of Robinia pseudoacacia and Ceratonia siliqua seeds under different single treatments.

\begin{tabular}{cccccccc}
\hline S.O.V. & d.f. & \multicolumn{3}{c}{ Robinia pseudoacacia } & \multicolumn{3}{c}{ Ceratonia siliqua } \\
\cline { 3 - 7 } & & $\begin{array}{c}\text { Sum of } \\
\text { squares }\end{array}$ & $\begin{array}{c}\text { Mean of } \\
\text { squares }\end{array}$ & $\mathbf{F}$ & $\begin{array}{c}\text { Sum of } \\
\text { squares }\end{array}$ & $\begin{array}{c}\text { Mean of } \\
\text { squares }\end{array}$ & F \\
\hline Treatments & 4 & 1663.53 & 415.88 & $10.41^{* *}$ & 2246.89 & 561.72 & $21.46^{* *}$ \\
\hline Error & 15 & 539.26 & 39.95 & & 392.55 & 26.17 \\
\hline Total & 19 & 2202.79 & & & & & \\
\hline
\end{tabular}

Table (2): The effect of various pre-sowing treatments on the germination percentage of Robinia pseudoacacia and Ceratonia siliqua seeds.

\begin{tabular}{ccc}
\hline Single Treatments & $\begin{array}{c}\text { Robinia } \\
\text { pseudoacacia }\end{array}$ & $\begin{array}{c}\text { Ceratonia } \\
\text { siliqua }\end{array}$ \\
\hline Control & $20.63 \mathrm{~d}$ & $28 \mathrm{c}$ \\
\hline $\begin{array}{l}\text { Mechanical } \\
\text { scarification }\end{array}$ & $26.25 \mathrm{c}$ & $11 \mathrm{~d}$ \\
\hline $\begin{array}{l}\text { Soaking in Hot } \\
\text { water (30 min) }\end{array}$ & $33.75 \mathrm{~b}$ & $36 \mathrm{~b}$ \\
\hline $\begin{array}{l}\text { Soaking in Hot } \\
\text { water (60 min) }\end{array}$ & $63.75 \mathrm{a}$ & $61 \mathrm{a}$ \\
\hline $\begin{array}{l}\text { Soaking in Hot } \\
\text { water (90 min) }\end{array}$ & $30 \mathrm{bc}$ & $40 \mathrm{~b}$ \\
\hline
\end{tabular}

\section{- The Second experiments (the interaction treatments):}

The results of data analysis (Table 3 ) showed that the effect of Sulfuric acid treatment on seed germination percentage of both species of Robinia pseudoacacia and Ceratonia siliqua seeds was significant at a probability of 0.01 . While the effect of soaking seeds in durations tap water is non-significant. Seeds of both species were soaked in sulfuric acid and then immersion in tap water for different duration showed highly significant differences in the probability of 0.01 (Table 3). Seeds of Robinia pseudoacacia in $90 \mathrm{~min}$ of Sulfuric acid treatment gave highest germination percentage (30\%) compared with $30 \mathrm{~min}$ of sulfuric acid $(12.5 \%)$ because the interaction of treatments may be decreasing germination percentage (Table 4) compared with the effect of the single factor, because these species just external dormancy causes for killing embryo of the seed. Seeds of Robinia pseudoacacia species were immersed of tap water for 24,48 and $72 \mathrm{~h}$ were non-significant differences $(20.83 \%, 20 \%$ and $22.5 \%$ ) respectively (Table 4 ). The highest seed germination $(42.5 \%)$ was observed when seeds treated with sulfuric acid at $90 \mathrm{~min}$ and soaked with one day of water (Table, 4). From the same table and same species, the lowest percentage of germination (10\%) was found in both interaction of $60 \mathrm{~min}$ in sulfuric acid with one day water and $30 \mathrm{~min}$ with one day tap water.

When the seeds of Ceratonia siliqua species treated in sulfuric acid at $60 \mathrm{~min}$ gave highest 
germination percentage (47\%) compared with 90 min and $30 \mathrm{~min}(43.33 \%$ and $28 \%)$ sequentially (Table 4). While seeds of this species treated with tap water for one, two and three days were non significant differences $(40 \%, 41.33 \%$ and $37 \%)$ sequentially (Table 4).

From the same table (4), the highest seed germination $(65 \%)$ was found when seeds treated with sulfuric acid at $60 \mathrm{~min}$ and soaking in water for one day. While the lowest percentage of germination $(22 \%)$ was found in both interaction of $30 \mathrm{~min}$ in sulfuric acid with three days water (Table 4).These results are agreeing with other researchers, such as (Goor and Barney 1968; Karschon 1960), where the seeds of Ceratonia siliqua impermeability seed coat were soaked in sulfuric acid for 1 hour and then in tap water for 24 hours have been increasing seed germination.
In addition, Saim and Derya (2014) were recommended the best treatment for overcoming seed dormancy of Ceratonia siliqua seeds was by immersing in sulfuric acid for 30 minutes, and then soaking in water for 2 days. Merou, et al. (2011) concluded that the broken seed dormancy and increasing seed germination of Albizia julibrissin seeds were soaking in sulfuric acid for 2 hours and immersion in $48 \mathrm{~h}$ of tap water. Similarly, Piotto and Di Noi (2003) have shown that the Carob seeds had been dipped in sulfuric acid and then washed in water, which was increasing seed germination. The most effective method for increasing seed germination of Ceratonia siliqua was showed in sulfuric acid for 30 minutes and immersing seeds in hot water for 60 minutes (Mansour 2013; Zaen El Deen, et al. 2014).

Table (3): Variance analysis of germination percentage of Robinia pseudoacacia and Ceratonia siliqua seeds under different interaction treatments.

\begin{tabular}{ccccccccc}
\hline S.O.V. & d.f. & \multicolumn{3}{c}{ Robinia pseudoacacia } & \multicolumn{3}{c}{ Ceratonia siliqua } \\
\cline { 2 - 8 } & & $\begin{array}{c}\text { Sum of } \\
\text { squares }\end{array}$ & $\begin{array}{c}\text { Mean of } \\
\text { squares }\end{array}$ & $\mathbf{F}$ & $\begin{array}{c}\text { Sum of } \\
\text { squares }\end{array}$ & $\begin{array}{c}\text { Mean of } \\
\text { squares }\end{array}$ & $\mathrm{F}$ \\
\hline $\mathrm{H}_{2} \mathrm{SO}_{4}$ & 2 & 875.46 & 437.73 & $33.73^{* *}$ & 922.23 & 461.11 & $16.33^{\star \star}$ \\
\hline Water/hours & 2 & 20.02 & 10.01 & 0.77 & 47.95 & 23.97 & 0.85 \\
\hline $\mathrm{H}_{2} \mathrm{SO}_{4}$ X Water & 4 & 1723.06 & 430.76 & $33.19^{* *}$ & 1208.31 & 302.07 & $10.70^{\star *}$ \\
\hline Error & 27 & 350.39 & 12.977 & & 762.24 & 28.23 & \\
\hline
\end{tabular}

Table (4): The effect of interaction pre-sowing treatments on the germination percentage (\%) of Robinia pseudoacacia and Ceratonia siliqua seeds.

\begin{tabular}{|c|c|c|c|c|}
\hline \multirow{3}{*}{$\mathrm{H}_{2} \mathrm{SO}_{4}$} & \multicolumn{3}{|c|}{ Robinia pseudoacacia } & \multirow[t]{3}{*}{ Effect of $\mathrm{H}_{2} \mathrm{SO}_{4}$} \\
\hline & \multicolumn{3}{|c|}{ WATER } & \\
\hline & $24 \mathrm{~h}$ & $48 \mathrm{~h}$ & 72 & \\
\hline $30 \mathrm{~min}$ & $10 c$ & $15 \mathrm{c}$ & $12.5 \mathrm{c}$ & $12.5 \mathrm{c}$ \\
\hline $60 \mathrm{~min}$ & $10 c$ & $12.5 c$ & $40 a b$ & $20.83 b$ \\
\hline $90 \mathrm{~min}$ & $42.5 a$ & $32.5 b$ & $15 c$ & $30 a$ \\
\hline Effect of water & $20.83 a$ & $20 a$ & $22.5 \mathrm{a}$ & \\
\hline
\end{tabular}

\begin{tabular}{|c|c|c|c|c|}
\hline \multirow{3}{*}{$\mathrm{H}_{2} \mathrm{SO}_{4}$} & \multicolumn{3}{|c|}{ Ceratonia siliqua } & \multirow[t]{3}{*}{ Effect of $\mathrm{H}_{2} \mathrm{SO}_{4}$} \\
\hline & \multicolumn{3}{|c|}{ WATER } & \\
\hline & $24 \mathrm{~h}$ & $48 \mathrm{~h}$ & $72 \mathrm{~h}$ & \\
\hline $30 \mathrm{~min}$ & $24 d$ & $38 \mathrm{bc}$ & $22 d$ & $28 b$ \\
\hline $60 \mathrm{~min}$ & $65 a$ & $37 \mathrm{bc}$ & $39 \mathrm{bc}$ & $47 a$ \\
\hline $90 \mathrm{~min}$ & $31 \mathrm{~cd}$ & $49 b$ & $50 \mathrm{~b}$ & $43.33 a$ \\
\hline Effect of water & $40 a$ & $41.33 a$ & $37 a$ & \\
\hline
\end{tabular}




\section{CONCLUSION}

Pre-sowing treatments of hot water at $60 \mathrm{~min}$. are increasing the maximum number of germination percentage for both species. In factorial interactions, both long and short duration of sulfuric acid (30 or $90 \mathrm{~min}$ ) decreases the germination percentage of Ceratonia siliqua, while, the long duration of sulfuric acid increase seed germination of Robinia pseudoacacia. In addition, the moderate duration interaction of both factors we obtain a moderate germination percentage.

\section{REFERENCES}

- Ahmed, G. B. (2015). Pretreatments effect on seed germination and early growth of Gleditsia triacanthos L. seedlings. Journal of University of Duhok., Vol. 18, No.1 (Agricultural and Veterinary. Sciences), Pp 47-55.

- Basbag M.; Aydin, A. and Ayzit, D. (2010).The Effect of Different Temperatures and Durations on the Dormancy Breaking of Black Locust (Robinia pseudoacacia L.) and Honey Locust (Gleditsia triacanthos L.) Seeds. Not Sci Biol. 2 (4): $125-128$.

- Baskin, C. C. and Baskin, J. M. (2014). Seeds: ecology, biogeography, and evolution of dormancy and germination, 2nd edn. San Diego, CA, USA: Academic/Elsevier.

- Batlle, I. and Tous J. (1997). Carob tree. Ceratonia siliqua $\mathrm{L}$. Promoting the conservation and use of underutilized and neglected crops. 17. Institute of Plant Genetics and Crop Plant Research. Gatersleben/IPGRI, Rome, Italy.

- Bonner, F.T.; Vozzo, J.A.; Elam, W.W. and Land, S.B. (1994).Tree Seed Technology Training Course. Instructor's Manual. General Technical Report SO-106, Southern Forest Experiment Station, New Orleans, Louisiana.

- Finch-Savage, W. E. and Leubner-Metzger, G. (2006) Seed dormancy and the control of germination. New Phytologist. 171, 501-523.

- Gebre, G. H. and Keram, N. S. (2004). Seed science and technology; 32(1): 255-260 (6).

- Goor, A. Y. and Barney, C. W. (1968).Forest tree planting in arid zones. New York: Ronald Press. $409 \mathrm{p}$.

- Holle, B. V.; Joseph, K. A.; Largay, E. F. and Lohnes, R. G. (2006).Facilitations between the introduced nitrogen-fixing tree, Robinia pseudoacacia, and nonnative plant species in the glacial outwash upland ecosystem of Cape Cod, MA. Biodiversity and Conservation 15, $2197-$ 2215.
- Karschon, R. (1960). Studies in nursery practice for carob (Ceratonia siliqua L.). Leafl. 14. Ilanot: Israel Department of Forestry. 8 p. (Forestry Abstracts 22: 3017, 1961).

- Lamlom, S.H. and Abdalrasol, E.M. (2016).Effects of Elevated Temperature on Carob (Ceratonia siliqua L.) Seed Germination from Al-Jabal Alakhdar Area, Libya. Acad. J. Plant Sci., 9 (1): 05-19, 2016.

- Mansour, W. (2013).The Effect of Some Mechanical and Chemical Treatments on Carob Seeds (Ceratonia siliqua L.) Germination. Tishreen University Journal for Research and Scientific Studies - Biological Sciences Series Vol. (35) No. (6) 2013.

- Masaka, K., Yamada, K. (2009). Variation in germination character of Robinia pseudoacacia L. (Leguminosae) seeds at individual tree level. Journal of Forest Research 14, 167-177.

- Merou, T.; Takos, I.; Konstantinidou, E.; Galatsidas, S. and Varsamis, G. (2011).Effect of different pretreatment methods on germination of Albizia julibrissin seeds. (2011), Seed Sci. \& Technol., 39, 248-252.

- Mitra, M.; Ali R. L. M. and Zahra O. A. (2013). The induction of seed germination using sulfuric acid, gibberellic acid and hot water in Robinia pseudoacacia L. Intl. Res. J. Appl. Basic. Sci. Vol., 4 (1), 96-98.

- Nasiri, M. and Eisavand, H. R. (2001).Evaluation the effect of Sulfuric acid on dormancy break and germination of Albizia julibrissin and Ceratonia siliqua seeds. Iranian Journal of Genetic and breeding Researches of Pasture and Forest Plants, 8: 95-111.

- Ortiz, P.L.; Arista, M. and Talavera, S. (1995).Germination ecology of Ceratonia siliqua L. (Cesalpinaceae), a Mediterranean tree. Flora 190, 89-95.

- Perez-Garcia, F. (2009).Germination characteristics and intra population variation in carob (Ceratonia siliqua L.) seeds. Spanish J. Agri. Res., 7: 398-406.

- Piotto, B. and Di Noi, A. (2003). Seed Propagation of Mediterranean Trees and Shrubs. Agenzia Nazionale per la Protezionedell'Ambiente (ANPA). Roma, Italy.

- Pipinis, E.; Milios, E.; Smiris, P. and Gioumousidis, C. (2011).Effect of acid scarification and cold moist stratification on the germination of Cercis siliquastrum L. seeds, Turk J Agric For, 35: 259-264.

- Poşta, D. S. and Camen, D. (2015).Research regarding the influence of the preparing methods on seed germination on Gleditsia triacanthos L. 
Romanian Biotechnological Letters, Vol. 20, No. 6.

- Rice, S.K.; Westerman, B. and Federici, R. (2004).Impacts of the exotic, nitrogen- fixing black locust (Robinia pseudoacacia) on nitrogen-cycling in a pine-oak ecosystem. Plant Ecology, 174, 97-107.

- Richardson, D.M. and Kluge, R.L. (2008). Seed banks of invasive Australian Acacia species in South Africa: roles in invasiveness and options for management. Perspectives in Plant Ecology, Evolution and Systematic 10, 161-177.

- Saied, A.S.; Gebauer, J. and Buerkert, A. (2008).Effects of different scarification methods on germination of Ziziphus spina-christi seeds. International Seed Testing Association.

- Saikou, E. S; Kabura, B. H. and Wen-Chi, H. (2008): Word Journal of Agricultural Sciences 4 (2): $213-219$.

- Saim, Z. B. and Derya, K. (2014).The Effects of Different Treatments on Carob (Ceratonia siliqua L.) Seed Germination. Turkish Journal of Agricultural and Natural Sciences Special Issue: 1 .

- SAS (2001). SAS User's Guide Statistics 21. SAS Institute, Cary, NC. USA.

- Susko, D.J. (2006) Effect of ovule position on patterns of seed maturation and abortion in Robinia pseudoacacia (Fabaceae). Canadian Journal of Botany, 84, 1259-1265.

- Talas-Ogras, T.; Ipekci., Z.; Bajrovic, K. and Gozukirmizi, N. (2005). Antibacterial activity of seed proteins of Robinia pseudoacacia, Fitoterapia 76(1), 67-72. DOI: 10.1016/j.fitote. 2004.10.020.

- Tlig, T., Gorai, M. and Neffati, M. (2008).Germination
Diplotaxisharra to temperature and salinity. Flora 203: 421-428.

- Tsakaldimi, M. N. and Ganatsas, P. P. (2001).Treatments improving seeds germination of two Mediterranean sclerophyll species Ceratonia siliqua and Pistacia lentiscus. Conference: Third Balkan Scientific Conference, At Sofia, Bulgaria, 2-6 October 2001, Volume: 2002, Volume II, pp. 119-127.

- Vasichkina, E. V.; Pavlova V. A. and Nefedyeva, E. E. (2014).Methods of seed germination stimulation exemplified by seeds of honey locust (Gleditsia triacanthos).ISSN 23064153.Вестн. Волгогр. гос.ун-та. Сер. 11, Естеств. науки.No.1 (7).

- Weber, E. (2003). Invasive Plant Species of the World.A Reference Guide to Environmental Weeds. CABI Publishing, Wallingford, UK.

- Youssef S., Baumel A., Véla E., Juin M., DumasE., Affre L., Tatoni T. (2011). Factors underlying the narrow distribution of the Mediterranean annual plant Arenaria provincialis (Caryophyllaceae). Folia Geobotanica, 46/327350.

- Zaen El Deen, E. M.; Omima, M. ;Abd, E. I. and Ghada, A. H. (2014). Studies on Carob (Ceratonia siliqua L.) Propagation-ISSN: 23192380, p-ISSN: 2319-2372. Volume 7, Issue 5 Ver. II (May. 2014), PP 31-40 www.iosrjournals.org.

- Zeleznik, J.D., and Skousen, J.G. (1996). Survival of three tree species on old reclaimed surface mines in Ohio. J. Environ. Qual. 25:1429-1435.

- Zoghi, Z.; Azadfar, D. and Kooch, Y. (2011).The effect of different treatments on seeds dormancy breaking and germination of caspian locust (Gleditschia caspica) tree. Annals of Biological $\begin{array}{llll}\text { Research } & 2 & \text { (5): }\end{array}$ 
زالبون لسهر دهمى خاثَبونا توقى داربين دوبينيا و سيراتونيا بكارئينانا سهر مدهريّن بهرومختيّن جورا و جور ل نهمامكهها مالتايين.

يوخته

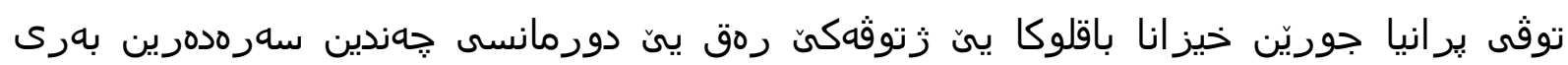

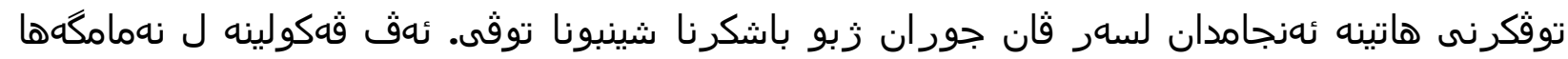

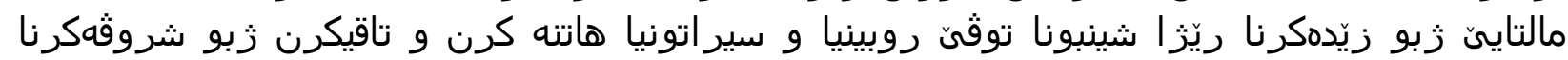

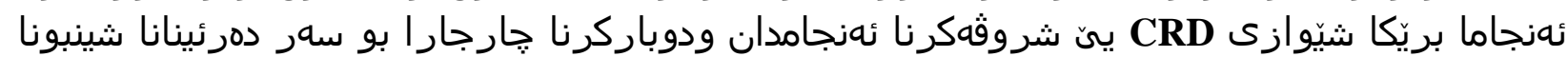

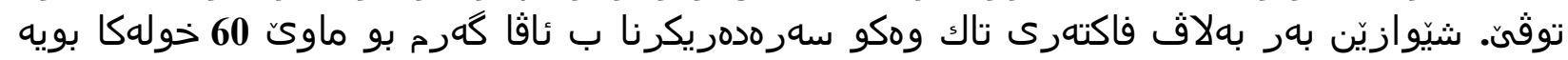

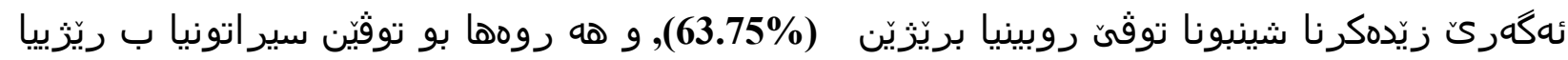

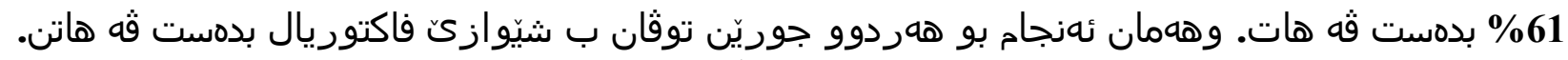

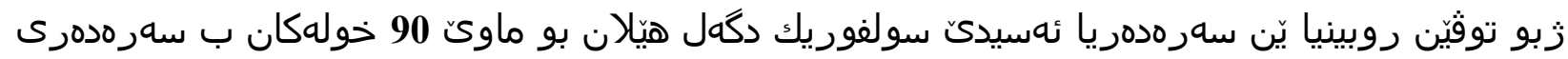

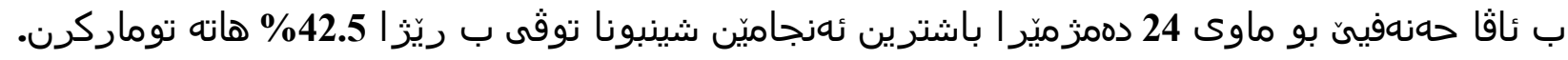

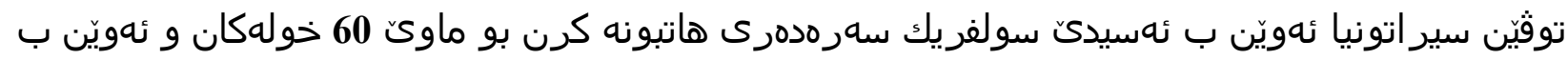

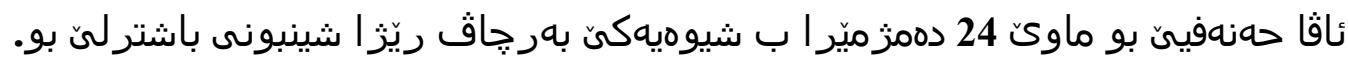

التغلب على كسر طور السكون لبذور اشجار الروبينيا و الكاروب باستخدام المعاملات الاولية المختلفة في مشتل غابات مالط الطا

الخلاصة

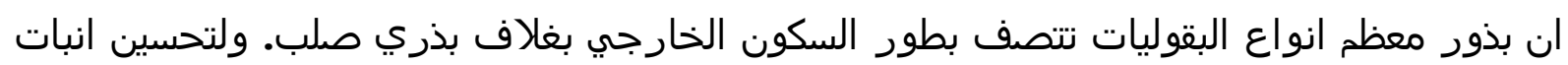

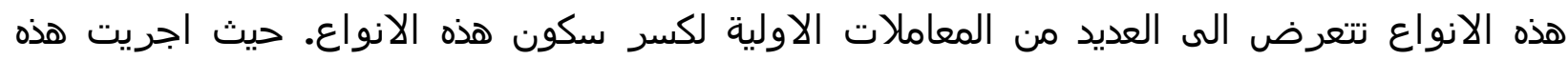

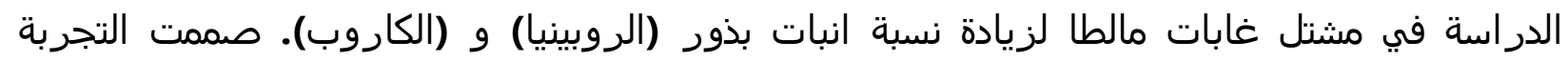

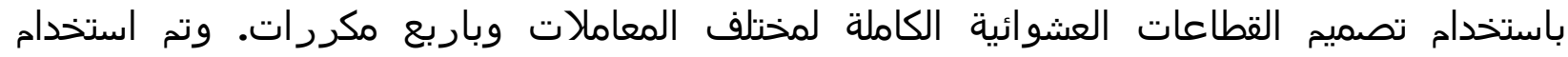

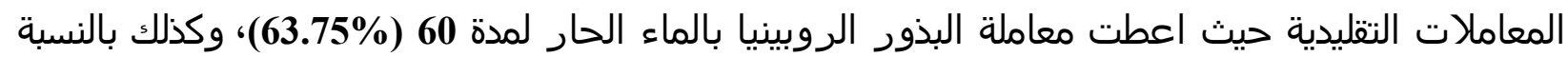
الى بذور الكاروب التي عوملت بنفس المعاملة (61\%).

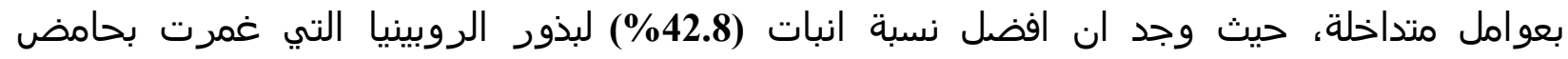

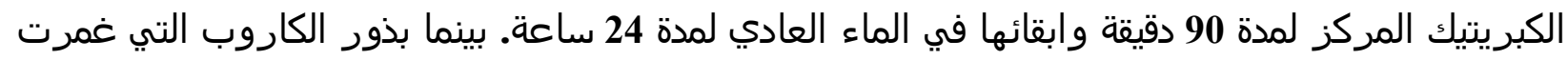

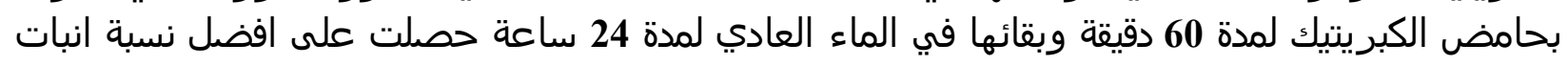

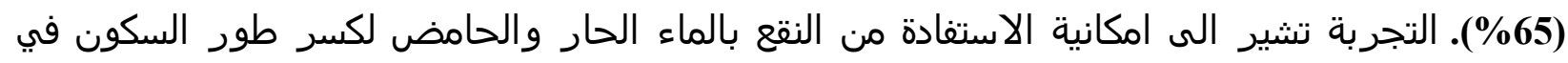
الروبينيا والكاروب على التربة تشر الي. 